\title{
WATER STRESS IN PASSION FRUIT CROPPING: AN APPROACH TO ITS DEVELOPMENT
}

Leandro Fogagnoli Contiero ${ }^{1}$ (D), José Carlos Cavichioli² (D), Lucas Aparecido Manzani Lisboa*1 (D), Rodrigo Aparecido Vitorino $^{2}$ (D), Samuel Bispo Ramos ${ }^{1}$ (D) \& Paulo Alexandre Monteiro de Figueiredo ${ }^{1}$

1 - São Paulo State University, College of Agricultural and Technological Sciences, Dracena, São Paulo, Brazil

2 - Paulista Agribusiness Technology Agency, Alta Paulista Regional Camp, Adamantina, São Paulo, Brazil

\section{Keywords:}

Passion fruit

Passiflora gibertii

Passiflora foetida

Passiflora edulis

Water stress

\begin{abstract}
In places with water restrictions, there is the occurrence of water stress, which compromises the entire cycle of passion fruit crop, causing damage to the vegetative and reproductive phase of the plant. Therefore, the objective of this work was to assess water stress in the passion fruit crop through an approach to its development. An experiment was carried out in May 2019 at São Paulo State University (Unesp), College of Agricultural and Technological Sciences located in the municipality of Dracena, State of São Paulo. The experimental design was completely randomized (DIC), in a $3 \times 3$ factorial arrangement, in which three passion fruit species were used: Passiflora gibertii; Passiflora foetida, and Passiflora edulis, interacting with three irrigation intervals, namely: 4,8 , and 12 days, with four replications, totaling 36 plots. It was found that the a 12-day interruption in the irrigation affects the growth of seedlings of different species of passion fruit, and the species $P$. gibertii has a growth rate higher than $P$. edulis and $P$. foetida. The species $P$. edulis showed lower contents of chlorophylls A, B, and total in relation to $P$. gibertii and $P$. foetida.
\end{abstract}

\section{Palavras-chave: \\ Maracujá \\ Passiflora gibertii \\ Passiflora foetida \\ Passiflora edulis \\ Estresse hídrico.}

\section{ESTRESSE HÍDRICO NA CULTURA DO MARACUJÁ: UMA ABORDAGEM NO SEU} DESENVOLVIMENTO

\section{RESUMO}

Em regiões que apresentam restrições hídricas passa a promover um estresse hídrico o que compromete todo o ciclo da cultura do maracujá, causando danos à fase vegetativa e reprodutiva da planta. Diante o exposto, esse trabalho teve por objetivo em avaliar estresse hídrico na cultura do maracujá através uma abordagem no seu desenvolvimento. Foi realizado um experimento no mês de maio de 2019 na Universidade Estadual Paulista (Unesp), Faculdade de Ciências Agrárias e Tecnológicas localizada no município de Dracena estado de São Paulo. O delineamento experimental foi inteiramente casualizado (DIC), em arranjo fatorial de $3 \times 3$, onde foram utilizadas três espécies de maracujá sendo elas: Passiflora gibertii; Passiflora foetida e Passiflora edulis, interagindo com três intervalos de irrigação, sendo eles: 4, 8 e 12 dias, com quatro repetições, totalizando 36 parcelas. Foi verificado que a suspensão da irrigação por 12 dias afeta o crescimento de mudas de diferentes espécies de maracujazeiros, sendo que a espécie $P$. gibertii tem um índice de crescimento superior a $P$. edulis e $P$. foetida. A espécie $P$. edulis apresentou menores taxas de clorofilas $\mathrm{A}, \mathrm{B}$ e total em relação à $P$. gibertii e $P$. foetida . 


\section{INTRODUCTION}

The cultivation of passion fruit is important in the Brazilian trade balance, as Brazil is the world's largest producer and consumer (FALEIRO; JUNQUEIRA, 2016), with an approximate production of 602 thousand tons per year (IBGE, 2018). However, its average productivity is still low, with $14 \mathrm{t} \mathrm{ha}^{-1}$ year $^{-1}$.

Its fruit can be used in many ways, but it is mainly used in the food industry, in which the juice is the major by-product (FERRAZ; LOT, 2006). In addition, its fruit can be consumed in its fresh form, it serves as a raw material in the production of condiments, cosmetics, in the pharmaceutical industry, among others. It is worth observing that the cultivation of passion fruit creates many jobs, in addition to being an income alternative for small farmers.

To obtain fruits in large quantities and of good quality, several technologies must be used during the management of the crop, including irrigation, which in the case of passion fruit, the most suitable is the localized drip irrigation. This technology is a viable alternative to improve productivity, and its purpose is to artificially increase water availability for the crop, meeting the water requirement during its cycle (SANTANA et al., 2009). This practice is poorly studied in the passion fruit crop, but it will result in a longer production period, which increases its productivity and fruit quality (RUGGIERO et al., 1996; CARVALHO et al., 2010).

Not using this technology in places with water restrictions compromises the entire crop cycle, causing water stress, which damages the vegetative and reproductive phases of the plant. Water stress causes a reduction in leaf area, which compromises the photosynthetic rate, thus the rate of carbon fixation in the dry matter is reduced, which compromises the extension of branches in addition to causing flower abortion and disarrangement at the fruit ripening (SANTOS et al., 2006). The impairment in fruit development reduces the amount of pulp in the fruits, resulting in a faded appearance and leading to their pre-mature fall (TEIXEIRA, 1989). Thus, the identification of passion fruit cultivars, with better potential for tolerance to water stress, is essential for the expansion of the crop in Brazil.

As a result, the objective of this work was to evaluate water stress in passion fruit crops by approaching their development.

\section{MATERIAL AND METHODS}

The experiment was carried out from May to July 2019 at the São Paulo State University (Unesp), College of Agricultural and Technological Sciences of Dracena, State of São Paulo, and conducted in a greenhouse covered with 1200-microns plastic light-diffusing film, with a ceiling height of 4.0 meters, and sides closed with a Sombrite ${ }^{\circledR}$-type screen with $50 \%$ of luminosity.

The experimental design was completely randomized (DIC), in a 3x3 factorial arrangement, where the following three species of passion fruit were used: Passiflora gibertii; Passiflora foetida, and Passiflora edulis, interacting with three irrigation intervals: 4,8 , and 12 days, with four replications, totaling 36 plots.

Each plot consisted of one plant. The seedlings were obtained from a local commercial nursery in the municipality of Adamantina, state of São Paulo, and had an average size of $20 \pm 3 \mathrm{~cm}$; with $6 \pm 1$ permanent leaves and 60 days of age. The seedlings were planted in plastic pots with a volumetric capacity of $9.0 \mathrm{dm}^{3}$ filled with Ferric Red Latosol (EMBRAPA, 2013) with the following chemical attributes as shown in Table 1.

Table 1. Soil chemical attributes used in the experiment establishment

\begin{tabular}{ccccccccccccc}
\hline $\mathrm{pH}$ & $\begin{array}{c}\mathrm{OM} \\
\mathrm{mg}\end{array}$ & $\mathrm{P}$ & $\mathrm{K}$ & $\mathrm{Ca}$ & $\mathrm{Mg}$ & $\begin{array}{c}\mathrm{SO}_{4}^{-2} \\
\mathrm{mg}\end{array}$ & $\begin{array}{c}\mathrm{H}+\mathrm{Al} \\
\mathrm{dm}\end{array}$ & $\begin{array}{c}\mathrm{Al} \\
\text {------ }\end{array}$ & $\mathrm{SB}$ & $\mathrm{CEC}$ & $\mathrm{V}$ & $\mathrm{m}$ \\
4.5 & 4.5 & 6.0 & 5.6 & 10.0 & 4.0 & 7.0 & 18.0 & 1.0 & 18.6 & 36.6 & 46.4 & 6.0 \\
\hline
\end{tabular}

*OM - Organic matter, SB - sum of bases, CEC - Cation exchange capacity, V - base saturation and $\mathrm{m}$ - Aluminum saturation 
The soil was corrected and fertilized according to the requirements of the crop and irrigated to determine the field capacity, where it was saturated and allowed to drain naturally. Estimates of evapotranspiration and water volume to be replaced at irrigation intervals were determined according to the methodology described by Casaroli and Lier (2008).

After 60 days from the beginning of the experiment, the following growth indices were determined: plant height (PHGI); stem diameter (SDGI) and leaf number (LNGI); dry matter of the aerial part and root (APDMDI) and root dry phytomass (RDMDP) which were obtained by drying in a circulation oven and air renewal at a constant temperature of $65^{\circ} \mathrm{C}$ until reaching constant weight. The indices (I) were determined using the Equation 1:

$I=\frac{M A V}{N D}$

Where:

$\mathrm{MAV}=$ mean average value; and

$\mathrm{ND}=$ Number of the days.

The concentrations of chlorophyll $a$, chlorophyll $b$ and total chlorophyll $\left(\mu \mathrm{mol} \mathrm{m}{ }^{-2}\right.$ ) were determined by direct reading with the use of the CCM-200 device, where the values were given by SPAD index (PARRY et al., 2014) and later converted into absolute values of the pigments as described by Chang and Troughton (1972).

For statistical evaluation, the variables were submitted to normality tests using the ShapiroWilk test. Once the precepts of each test were met, analysis of variance was performed using the $\mathrm{F}$ test $(\mathrm{p}<0.05)$, and its means were compared by Tukey's test at $5 \%$ probability. Also, the $r$-value of the Pearson correlation was determined (Banzatto and Kronka, 2013) and the statistical program RStudio (R Core Team, 2015) was used.

\section{RESULTS AND DISCUSSION}

The highest plant height growth index was obtained in the 4-day irrigation interval, not differing from the 8-day interval. The passion fruit species $P$. gibertii had the highest index in relation to the other species (Table 2).

No differences were found between irrigation intervals neither among passion fruit species for the stem diameter growth rate.

The different irrigation intervals did not influence the growth rate of the number of leaves; nevertheless, the species $P$. foetida had the highest rate, statistically differing from the other passion fruit trees.

Plants irrigated at 12-day intervals showed the lowest levels of aerial part dry matter deposition, differing from plants irrigated every 4 days. There were no differences between the passion fruit species for this variable.

No significant difference was found between the means of irrigation intervals in the root dry matter deposition index, where the species $P$. edulis was inferior to $P$. gibertii and $P$. foetida.

The mean values of chlorophyll A, Chlorophyll B, and total Chlorophyll are shown in Table 3. It was observed that for the three variables, the lowest chlorophyll rates were obtained in the 4-day irrigation interval and that the species $P$. foetida stood out in relation to the other passion fruit, showing the best mean for chlorophyll A, Chlorophyll B, and total Chlorophyll.

Figure 1 shows the Pearson correlations between the variables analyzed in the passion fruit species when grown in different irrigation intervals. Significant positive correlations was found between total chlorophyll (CT) with chlorophyll $\mathrm{A}(\mathrm{CAT})$ (Figure 2A) with an $\mathrm{r}=1(\mathrm{p}<0.01)$ and with chlorophyll B (CBT) (Figure 2B) with an $r=1 \quad(p<0.01)$ and between chlorophyll $A$ and chlorophyll B (Figure 2C) with $r=1(p<0.01)$. The aerial part dry matter deposition index (APDMDI) correlated positively and significantly with the plant height growth index (PHGI) (Figure 2D) with an $\mathrm{r}=0.48(\mathrm{p}<0.01)$ and with the leaf number growth index (LNGI) (Figure 2D) with an $r=0.44$ $(\mathrm{p}<0.01)$.

Each crop has a development stage in which water deficit causes a drop in production, thus the 
Table 2. Mean values of plant height growth index (PHGI); stem diameter growth index (SDGI); leaf number growth index (LNGI); aerial part dry matter deposition index (APDMDI); Root dry matter deposition index (RDMDI) of passion fruit species cultivated in different irrigation intervals. Dracena, SP, 2019

\begin{tabular}{|c|c|c|c|c|}
\hline & \multicolumn{4}{|c|}{ Plant height growth index $\left.\left(\mathrm{cm}^{-d_{a y}}\right)^{-1}\right)$} \\
\hline & 4 days & 8 days & 12 days & Mean (ssp) \\
\hline P. gibertii & 4.32 & 4.25 & 3.24 & $3.93 \mathrm{a}$ \\
\hline P. foetida & 3.19 & 2.78 & 2.29 & $2.76 \mathrm{~b}$ \\
\hline P. edulis & 2.81 & 1.80 & 1.71 & $2.10 \mathrm{~b}$ \\
\hline \multirow[t]{5}{*}{ Mean (days) } & $3.44 \mathrm{a}$ & $2.94 \mathrm{ab}$ & $2.41810 \mathrm{~b}$ & \\
\hline & LSD: 0.65 & CV $(\%): 22.02$ & OM: 2.93 & \\
\hline & $F(S): 24.70 * *$ & $\mathrm{~F}(\mathrm{I}): 7.57 * *$ & $\mathrm{~F}(\mathrm{SxI}): 0.71 \mathrm{~ns}$ & \\
\hline & \multicolumn{4}{|c|}{ Stem diameter growth index $\left(\mathrm{mm}^{2}\right.$ day $\left.^{-1}\right)$} \\
\hline & 4 days & 8 days & 12 days & Mean (ssp) \\
\hline P. gibertii & 0.09 & 0.09 & 0.10 & 0.09 \\
\hline P. foetida & 0.10 & 0.07 & 0.10 & 0.09 \\
\hline P. edulis & 0.10 & 0.08 & 0.10 & 0.09 \\
\hline \multirow[t]{5}{*}{ Mean (days) } & 0.09 & 0.08 & 0.10 & \\
\hline & LSD: 0.02116 & CV $(\%): 21.67$ & OM: 0.09 & \\
\hline & $\mathrm{F}(\mathrm{S}): 0.16 \mathrm{~ns}$ & $\mathrm{~F}(\mathrm{I}): 1.95 \mathrm{~ns}$ & $\mathrm{~F}(\mathrm{SxI}): 0.78 \mathrm{~ns}$ & \\
\hline & \multicolumn{4}{|c|}{ Leaf number growth index $\left(n^{\circ}\right.$ leaves.day $\left.{ }^{-1}\right)$} \\
\hline & 4 days & 8 days & 12 days & Mean (ssp) \\
\hline P. gibertii & 0.31 & 0.24 & 0.18 & $0.24 \mathrm{~b}$ \\
\hline P. foetida & 0.46 & 0.49 & 0.43 & $0.46 \mathrm{a}$ \\
\hline P. edulis & 0.19 & 0.15 & 0.14 & $0.16 \mathrm{~b}$ \\
\hline \multirow[t]{5}{*}{ Mean (days) } & $0.32^{-}$ & 0.29 & 0.25 & \\
\hline & LSD: 0.13 & CV $(\%): 45.67$ & OM: 0.29 & \\
\hline & $\mathrm{F}(\mathrm{S}): 15.78 * *$ & $\mathrm{~F}(\mathrm{I}): 0.80 \mathrm{~ns}$ & $\mathrm{~F}(\mathrm{SxI}): 0.19 \mathrm{~ns}$ & \\
\hline & \multicolumn{4}{|c|}{ Aerial part dry matter deposition index (g.day $\left.{ }^{-1}\right)$} \\
\hline & 4 days & 8 days & 12 days & Mean (ssp) \\
\hline P. gibertii & 0.213 & 0.218 & 0.168 & 0.19 \\
\hline P. foetida & 0.196 & 0.210 & 0.189 & 0.19 \\
\hline P. edulis & 0.212 & 0.185 & 0.168 & 0.18 \\
\hline \multirow[t]{5}{*}{ Mean (days) } & $0.207 \mathrm{a}$ & $0.204 \mathrm{ab}$ & $0.175 \mathrm{~b}$ & \\
\hline & LSD: 0.03 & CV $(\%): 15.71$ & OM: 0.195 & \\
\hline & $\mathrm{F}(\mathrm{S}): 0.47 \mathrm{~ns}$ & $\mathrm{~F}(\mathrm{I}): 3.94 *$ & $\mathrm{~F}(\mathrm{SxI}): 0.87 \mathrm{~ns}$ & \\
\hline & \multicolumn{4}{|c|}{ Root dry matter deposition index (g.day $\left.{ }^{-1}\right)$} \\
\hline & 4 days & 8 days & 12 days & Mean (ssp) \\
\hline P. gibertii & 0.088 & 0.081 & 0.082 & $0.084 \mathrm{a}$ \\
\hline P. foetida & 0.062 & 0.065 & 0.052 & $0.060 \mathrm{~b}$ \\
\hline P. edulis & 0.089 & 0.062 & 0.073 & $0.074 \mathrm{ab}$ \\
\hline \multirow[t]{3}{*}{ Mean (days) } & 0.079 & 0.069 & 0.069 & \\
\hline & LSD: 0.018 & CV $(\%): 24.75$ & OM: 0.073 & \\
\hline & $\mathrm{F}(\mathrm{S}): 5.20 *$ & $\mathrm{~F}(\mathrm{I}): 1.29 \mathrm{~ns}$ & $\mathrm{~F}(\mathrm{SxI}): 0.81 \mathrm{~ns}$ & \\
\hline
\end{tabular}

** significant at the $1 \%$ probability level $(\mathrm{p}<0.01) ; *$ significant at $5 \%$ probability level $(0.01=<\mathrm{p}<0.05)$; ns not significant $(\mathrm{p}>=0.05)$; Means followed by the same letter are not statistically different from each other. Test of Tukey was an applied at the $5 \%$ probability level. OM $=$ Overall mean; $\mathrm{CV}=$ Coefficient of variation

magnitude of effects of the water deficit differs between and within species, as cultivars have different growth and development characteristics (RODRIGUES et al., 1998). In the case of passion fruit, the species $P$. gibertii had a higher growth rate when compared to the species $P$. edulis and $P$. foetida. No differences were found between these species for the indices of diameter growth and 


\section{WATER STRESS IN PASSION FRUIT CROPPING: AN APPROACH TO ITS DEVELOPMENT}

Table 3. Mean values of Total chlorophyll, chlorophyll A and chlorophyll B, of the passion fruit species cultivated in different irrigation intervals. Dracena, SP, 2019

\begin{tabular}{|c|c|c|c|c|}
\hline & \multicolumn{4}{|c|}{ Total Chlorophyll $\left.(\mu \mathrm{mol} \mathrm{m})^{-2}\right)$} \\
\hline & 4 days & 8 days & 12 days & Mean (ssp) \\
\hline P. gibertii & 186.49 & 443.76 & 487.59 & $372.61 \mathrm{a}$ \\
\hline P. foetida & 287.86 & 545.69 & 557.05 & $463.53 \mathrm{a}$ \\
\hline P. edulis & 147.68 & 286.75 & 303.82 & $246,08 \mathrm{~b}$ \\
\hline \multirow[t]{5}{*}{ Mean (days) } & $207.34 \mathrm{~b}$ & $425.40 \mathrm{a}$ & $449.48 \mathrm{a}$ & \\
\hline & LSD: 117.41 & $\mathrm{CV}(\%): 32.19$ & OM: 360.74 & \\
\hline & $\mathrm{F}(\mathrm{S}): 10.61 * *$ & $\mathrm{~F}(\mathrm{I}): 15.83 * *$ & $\mathrm{~F}(\mathrm{SxI}): 0.53 \mathrm{~ns}$ & \\
\hline & \multicolumn{4}{|c|}{ Chlorophyll A $\left(\mu \mathrm{mol} \mathrm{m} \mathrm{m}^{-2}\right)$} \\
\hline & 4 days & 8 days & 12 days & Mean (ssp) \\
\hline P. gibertii & 155.64 & 363.17 & 396.66 & $305.16 \mathrm{a}$ \\
\hline P. foetida & 234.58 & 444.74 & 463.52 & $380.95 \mathrm{a}$ \\
\hline P. edulis & 120.75 & 231.86 & 248.96 & $200.52 \mathrm{~b}$ \\
\hline \multirow[t]{5}{*}{ Mean (days) } & $170.32 \mathrm{~b}$ & $346.59 \mathrm{a}$ & $369.71 \mathrm{a}$ & \\
\hline & LSD: 94.12 & $\mathrm{CV}(\%): 31.50$ & OM: 295.54 & \\
\hline & $\mathrm{F}(\mathrm{S}): 11.36^{* *}$ & $\mathrm{~F}(\mathrm{I}): 16.46 * *$ & $\mathrm{~F}(\mathrm{~S} \times \mathrm{I}): 0.54 \mathrm{~ns}$ & \\
\hline & \multicolumn{4}{|c|}{ Chlorophyll B $\left(\mu \mathrm{mol} \mathrm{m} \mathrm{m}^{-2}\right)$} \\
\hline & 4 days & 8 days & 12 days & Mean (ssp) \\
\hline P. gibertii & 50.76 & 121.05 & 133.71 & $101.84 \mathrm{a}$ \\
\hline P. foetida & 78.21 & 147.12 & 154.50 & $126.61 \mathrm{a}$ \\
\hline P. edulis & 40.24 & 77.95 & 82.98 & $67.06 \mathrm{~b}$ \\
\hline \multirow[t]{3}{*}{ Mean (days) } & $56.40 \mathrm{~b}$ & $115.37 \mathrm{a}$ & $123.73 \mathrm{a}$ & \\
\hline & LSD: 32.00 & CV $(\%): 32.13$ & OM: 98.50 & \\
\hline & $\mathrm{F}(\mathrm{S}): 10.71 * *$ & $\mathrm{~F}(\mathrm{I}): 16.12^{* *}$ & $\mathrm{~F}(\mathrm{SxI}): 0.54 \mathrm{~ns}$ & \\
\hline
\end{tabular}

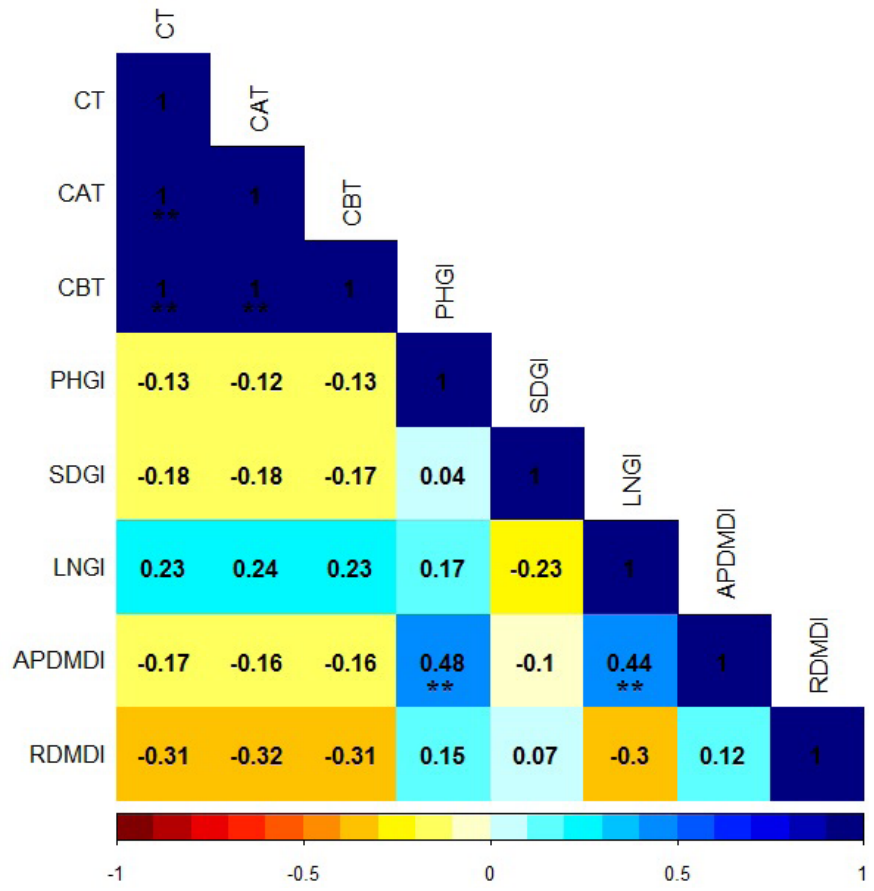

Figure 1. Pearson correlations among variables analyzed in passion fruit species when cultivated in different irrigation intervals. $\mathrm{CT}=$ Total Chlorophyll; $\mathrm{CAT}=$ total Chlorophyll $\mathrm{A} ; \mathrm{CBT}=$ Total Chlorophyll $\mathrm{B} ; \mathrm{PHGI}=$ Plant height growth index; SDGI $=$ Stem diameter growth index; LNGI $=$ Leaf number growth index; APDMDI = aerial part dry matter deposition index and RDMDI = Root dry matter deposition index. Dracena, 2019 

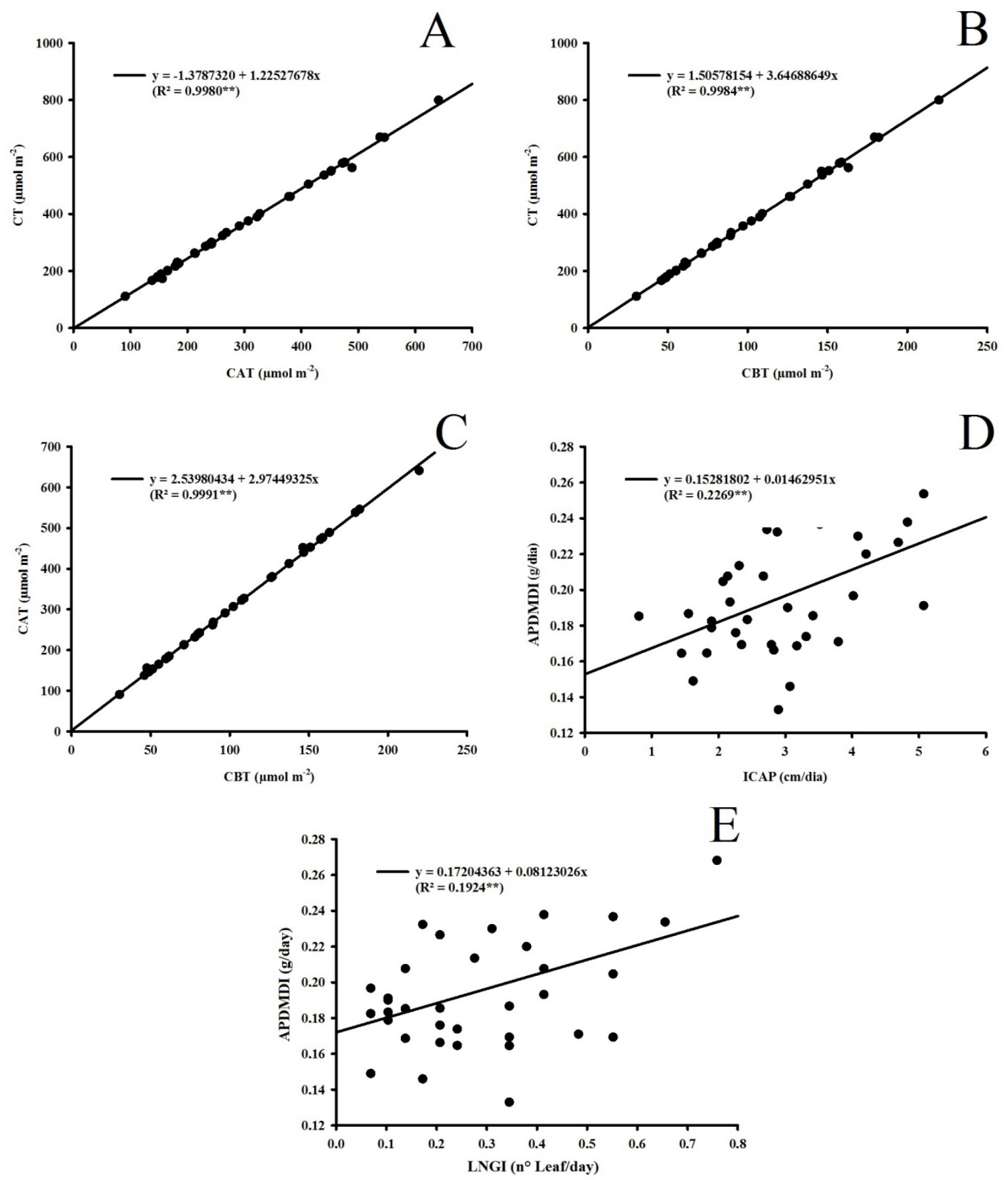

Figure 2. Linear regressions after Pearson correlation analysis among the variables analyzed in passion fruit species when grown in different irrigation intervals. $\mathrm{CT}=$ Total Chlorophyll; $\mathrm{CAT}=$ total Chlorophyll A; CBT = Total Chlorophyll B; PHGI = Plant height growth index; SDGI $=$ Stem diameter growth index; LNGI $=$ Leaf number growth index; APDMDI $=$ aerial part dry matter deposition index and RDMDI = Root dry matter deposition index. Dracena, 2019

aerial dry matter deposition. According to Simon and Karnatz (1983), factors such as nutritional deficiencies and water stress, combined with short days and low air and soil temperatures, can restrict the growth and production potential of the passion fruit.

It could have been observed in this work that the interruption in irrigation for 12 days during the formation of the passion fruit seedlings harmed the plant growth and the aerial part dry matter 
deposition index; however, it did not affect the stem diameter growth index neither the root dry matter deposition index. In cases of water deficit, plants respond to physiological factors in an attempt to maintain the water present in the soil as much as possible to use it whenever is necessary (SANTOS; CARLESSO, 1998). Cultures can challenge and adapt to conditions of water stress by activating several defense mechanisms and altering cell metabolism.

Several morphological, biochemical, and physiological processes of plants are affected by water deficit, especially by increased diffusive resistance to water vapor, through stomatal closure, then the supply of carbon dioxide and transpiration for the photosynthetic process is reduced, consequently, cell growth is reduced and photorespiration increases (SHINOZAKI; YAMAGUCHI-SHINOZAKI, 2007). When the first signs of stress occur, the processes of signaling and transcriptional controls are initiated. Such processes promote the activation of stressresponsive mechanisms, restore cell homeostasis, and also to protect and repair damaged proteins and membranes (HARFOUCHE et al., 2014).

According to Mendes et al. (2007), water stress affects several physiological processes of the plant, particularly stomatal conductance, leaf water potential, and leaf transpiration, with the rise in leaf temperature and a reduction in photosynthetic processes. Dodds et al. (1997) claim that the reduction of water availability affects the rate of photosynthesis, the size and number of leaves and fruits, also affecting its quality. It was observed in this work that the interruption of irrigation for up to 12 days in the formation of passion fruit seedlings did not influence the growth rate of the number of leaves for the species $P$. gibertii, $P$. foetida, and $P$. edulis.

The same effects were also observed by Taiz and Zeiger (2017), reporting that the most visible response of plants under water deficit is the reduction of leaf area, leaf senescence, and abscission as well as stomata closure. Fornasieri Filho (2008) corroborates the other authors by reporting that under reduced water availability, plants tend to respond by reducing the leaf area and closing the stomata, which provides a reduction in water loss through transpiration; however, preventing $\mathrm{CO}_{2}$ from entering the photosynthesis, resulting in lower potential yield.

It was found that for the three variables, the lowest chlorophyll rates were obtained in the 4-day irrigation interval and that the species $P$. foetida stood out in relation to the other passion fruit trees, showing the best means for chlorophyll $\mathrm{a}, \mathrm{b}$, and total chlorophyll. Chlorophyll $\mathrm{a}$ is the pigment used to carry out the photochemical phase of photosynthesis, while chlorophyll $b$ helps to absorb light and transfer radiant energy to the reaction centers (STREIT et al., 2005).

\section{CONCLUSIONS}

- A 12-day interruption in the irrigation affects the growth of seedlings of different species of passion fruit.

- $\quad$ The species $P$. gibertii has a higher growth rate than $P$. edulis and $P$. foetida.

- P. edulis has lower rates of chlorophyll A, chlorophyll B, and total chlorophyll.

\section{AUTHORSHIP CONTRIBUTION STATEMENT}

CONTIERO, L.F.: Conceptualization, Formal Analysis, Project administration, Resources, Supervision; CAVICHIOLI, J.C.: Conceptualization, Funding acquisition, Investigation, Project administration, Supervision; LISBOA, L.A.M.: Data curation, Formal Analysis, Investigation, Methodology, Supervision; VITORINO, R.A.: Conceptualization, Funding acquisition, Project administration, Supervision; RAMOS, S.B.: Conceptualization, Data curation, Formal Analysis, Resources; FIGUEIREDO, P.A.M.: Funding acquisition, Project administration, Resources, Supervision.

\section{DECLARATION OF INTERESTS}

The authors declare that they have no known competing financial interests or personal relationships that could have appeared to influence the work reported in this paper. 


\section{REFERENCES}

BANZATTO, D. A.; KRONKA, S. N. Experimentação Agrícola. 4.ed. Funep, 2013.

CARVALHO, J. A.; KOETZ, M.; SOUSA, A. M. G.; SOUZA, K. J. Desenvolvimento e produtividade do maracujazeiro-amarelo irrigado sob diferentes lâminas de irrigação em ambiente protegido e natural. Engenharia Agrícola, Jaboticabal, v.30, n.5, p.862-874, 2010.

R CORE TEAM. R: A language and environment for statistical computing. $\mathrm{R}$ Foundation for Statistical Computing, Vienna, Austria, 2014. URL: https://www.R-project.org/

CASAROLI, D.; LIER, Q. J. Criteria for pot capacity determination. Revista Brasileira de Ciência do Solo. v.32, n.1, p. 56-66, 2008.

CHANG F. H.; TROUGHTON J. H. Chlorophyll $\mathrm{a} / \mathrm{b}$ ratios in $\mathrm{C} 3$ and $\mathrm{C} 4$-plants. Photosynthetica, v.6, p.57-65, 1972.

DODDS, G. T.; TRENHOLM, L.; RAJABIPOUR, A.; MADRAMOOTO, C. A.; NORRIS, E. R. Yield and quality of tomato fruit under water-table management. Journal of the American Society for Horticultural Science, p.491-498, 1997.

EMPRESA BRASILEIRA DE PESQUISA AGROPECUÁRIA - EMBRAPA. Sistema brasileiro de classificação de solos. 3.ed. Brasília, 2013.

FALEIRO, F. G.; JUNQUEIRA, N. T. V. Maracujá: o produtor pergunta, a Embrapa responde. Embrapa Cerrados-Livro técnico (INFOTECA-E), 2016.

FERRAZ, J. V.; LOT, L. Fruta para consumo in natura tem boa perspectiva de renda. In: AGRIANUAL 2007: anuário da agricultura brasileira. Maracujá. São Paulo: FNP Consultoria e Comércio, 2006.

FORNASIERI FILHO, D. Manual da cultura do trigo. Funep, Jaboticabal, 2008,
HARFOUCHE, A.; MEILAN, R.; ALTMAN, A. Molecular and physiological responses to abiotic stress in forest trees and their relevance to tree improvement. Tree Physiology, v. 34, n. 11, p. 1181-1198, 2014.

IBGE - Instituto Brasileiro de Geografia e Estatística. Maracujá: área colhida e quantidade produzida. Brasília, 2018. (Produção Agrícola Municipal, 2018). Available: < https://sidra.ibge. gov.br/tabela/1613\#resultado $>$. Accessed Apr. 18, 2020 .

MENDES, R. M. S.; TÁVORA, F. J. A. F.; PINHO, J. L. N.; PITOMBEIRA, J. B. Relações fonte-dreno em feijão-de-corda submetido à deficiência hídrica. Ciência Agronômica, v.38, p.95-103, 2007.

PARRY C.; BLONQUIST C. M.; BUGBEE B. In situ measurement of leaf chlorophyll concentration: analysis of the optical/absolute relationship. Plant, Cell and Environment, v.37, p.2508-2520, 2014.

RIZZI, L. C.; RABELLO, L. A.; MOROZINI FILHO, W.; SAVASAKI, E. T.; KAVATI, R. Cultura do maracujá-azedo. Campinas: Coordenadoria de Assistência Técnica Integral, SAA, 1998.

RUGGIERO, C.; SÃO JOSÉ, A. R.; VOLPE, C. A.; OlIVEIRA, J. C.; DURIGAN, J. F.; BAUMGARTNER, J. G.; SILVA, J. R.; NAKAMURA, K.; FERREIRA, M. E.; KAVATI, R.; PEREIRA, V. P. Maracujá para exportação: aspectos técnicos de produção. Brasília: EmbrapaSPI, 1996.

RODRIGUES, O.; LHAMBY, J. C. B.; DIDONET, A. D.; MARCHESE, J. A.; SCIPIONI, C. Efeito da deficiência hídrica na produção de trigo. Pesquisa Agropecuária Brasileira, v.33, n.6, p.839-846, 1998.

SANTANA, M. J.; CARVALHO, J.A.; ANDRADE, M. J.B.; GERVÁSIO, G. G.; BRAGA, J. C.; LEPRI, E.B. Viabilidade técnica e econômica da aplicação de água na cultura do feijoeiro comum (Phaseolus Vulgaris L.). Ciência e Agrotecnologia, v. 33, n. 02, p. 532-538, 2009. 
SANTOS, F.A.; PETILIO, A. A.; BOSQUÊ, G.G. A influência da água e do nitrogênio na cultura do maracujá (Passiflora edulis). Revista Científica Eletrônica de Agronomia, v. 5, n. 10, p. 8-13, 2006.

SANTOS, R. F.; CARLESSO, R. Déficit hídrico e os processos morfológico e fisiológico das plantas. Revista Brasileira de Engenharia Agrícola Ambiental. v. 2, n. 3, 1998.

SHINOZAKI, K; YAMAGUCHI-SHINOZAKI, $\mathrm{K}$. Gene networks involved in drought stress response and tolerance. Journal of Experimental Botany, v. 58, n. 2, p. 221-227, 2007.

SIMON, P.; KARNATZ, A. Effect of soil anda ir temperature on growth and flower formation of purple passion fruit (Passiflora edulis Sims). Acta Horticulturae. v.139, p.120-128, 1983.

STREIT, N. M.; CANTERLE, L. P.; CANTO, M. W.; HECKTHEUER, L. H. H. As clorofilas. Ciência Rural, v.35, n.3, p. 748-755, 2005.

TAIZ, L.; ZEIGER, E.; MOLLER, I.; MURPHY, A. Fisiologia e desenvolvimento vegetal. 6. ed. Porto Alegre: Artmed, 2017

TEIXEIRA, D. M. M. Efeito de vários níveis de fertirrigação na cultura do maracujazeiro amarelo (Passiflora edulis var. flavicarpa). Dissertação (Mestrado em Irrigação e Drenagem) - Escola Superior de Agricultura Luiz de Queiroz, University of São Paulo, Piracicaba, 1989. 